\title{
EFFECT OF THE FILTRATION WITH BLEACHING EARTHS ON SEVERAL QUALITY PARAMETERS OF THE BIODIESEL OBTAINED FROM AFRICAN PALM OIL
}

\author{
EFECTO DE LA FILTRACIÓN CON TIERRAS DE BLANQUEO \\ SOBRE ALGUNAS VARIABLES DE CALIDAD DEL BIODIESEL \\ OBTENIDO A PARTIR DEL ACEITE DE PALMA
EFEITO DA FILTRAÇÃO COM TERRAS DE BRANQUEAMENTO SOBRE ALGUMAS VARIÁVEIS DE QUALIDADE DO BIODIESEL OBTIDO A PARTIR DO ÓLEO DA PALMEIRA AFRICANA

\author{
Alberto Ricardo Albis Arrieta ${ }^{1 *}$; Carlos Alberto Barros Mendoza ${ }^{1}$; Oscar Eliecer Cabarcas Núñez ${ }^{1}$ \\ 'Facultad de Ingeniería, Universidad del Atlántico, Barranquilla-Colombia \\ e-mail: albertoalbis@uniatlantico.edu.co
}

(Received: Mar. 9, 2016; Accepted: Mar. 30, 2017)

\begin{abstract}

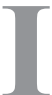

$\mathrm{n}$ this work, we studied the performance of bleaching earths as removal agents of Total Contamination from samples of Colombian biodiesel obtained from palm oil. The effect of temperature and the dose of three commercial adsorbents were studied on quality parameters, Total Contamination and moisture of biodiesel. Results showed a complex behavior of the study variables on Total Contamination and final moisture; but either almost or no effects on other quality parameters such as free glycerin, total glycerin and pour point. Response surfaces showed that the values of the manipulated variables that improved the removal of Total Contamination in biodiesel also increased final moisture in the samples. Therefore, it was necessary to compute optimum values using desirability functions, which gave values for Total Contamination and final moisture, of $5.5 \mathrm{mg} / \mathrm{kg}$ and $562 \mathrm{mg} / \mathrm{kg}$, respectively, using $0.48 \%$ of Bleaching Earth BE 1 at $30^{\circ} \mathrm{C}$.
\end{abstract}

Keywords: Bleaching Earths, Total Contamination, Biodiesel, Moisture, Precipitate, Adsorption.

How to cite: Albis-Arrieta,A.R., Barros-Mendoza, C,A., Cabarcas-Núñez, O,E. J., Almanza, O.,. (2017). Effect of the filtration with Bleaching Earths on several quality parameters of the Biodiesel obtained from African Palm Oil. CT\&F - Ciencia, Tecnología y Futuro., 6(5), 59-70.

*To whom correspondence should be sent 


\section{RESUMEN}

E

n este trabajo, se estudió el uso de tierras de blanqueo como agentes de remoción de la contaminación total de muestras de biodiesel colombiano obtenido a partir del aceite de palma africana. Se estudiaron el efecto de la temperatura y la dosis de tres adsorbentes comerciales sobre los parámetros de calidad, contaminación total y humedad del biodiesel. Los resultados muestran un comportamiento complejo de las variables de estudio sobre la contaminación total y la humedad, pero efectos nulos o favorables sobre otras variables de calidad, tales como glicerina libre, glicerina total y punto de fluidez. Las superficies de respuesta, mostraron que las condiciones que favorecen la remoción de la contaminación total aumentan el contenido de humedad final del biodiesel, por lo que se hizo necesario calcular los posibles óptimos de operación a través de funciones de deseabilidad, las cuales mostraron valores para las variables contaminación total y humedad de $5.5 \mathrm{mg} / \mathrm{kg}$ y $562 \mathrm{mg} / \mathrm{kg}$, respectivamente, usando $0.48 \%$ de la tierra de blanqueo BE 1 a $30^{\circ} \mathrm{C}$.

Palabras clave: Tierras de Blanqueo, Contaminación Total, Biodiesel, Humedad, Precipitado, Adsorción

\section{RESUMO}

Teste trabalho estudou-se o uso das terras de branqueamento como agentes de remoção da contaminação total sobre amostras de biodiesel colombiano obtido a partir do óleo de dendezeiro (palma africana). Estudou-se o efeito da temperatura e a dose de três absorventes comerciais sobre os parâmetros de qualidade, a contaminação total e umidade do biodiesel. Os resultados mostram um comportamento complexo das variáveis de estudo sobre a contaminação total e a umidade; porém, mostram efeitos nulos ou favoráveis sobre outras variáveis de qualidade, tais como glicerina livre, glicerina total e ponto de fluidez. As superfícies de resposta mostraram que as condições que favorecem a remoção da contaminação total aumentam o conteúdo de umidade final do biodiesel, pelo qual foi preciso calcular os possíveis valores ótimos de operação através de funções de desejabilidade, obtendo dados de contaminação total e umidade de $5,5 \mathrm{mg} / \mathrm{kg}$ y $562 \mathrm{mg} / \mathrm{kg}$, respectivamente, usando $0,48 \%$ de terra de branqueamento $\mathrm{BE} 1$ a $30^{\circ} \mathrm{C}$.

Palavras-chave: Terras de Branqueamento, Contaminação Total, Biodiesel, Umidade, Precipitado, Adsorção. 


\section{INTRODUCTION}

The current concern for producing fuels of low impact on the environment has originated the development of the so-called first generation biofuels. Among them, biodiesel has been adopted in several countries, including Colombia, where it is produced from African Palm Oil Ley 939 de 2004 (Congreso de Colombia, 2004). Several problems have been identified since the early start of its commercialization, including plugging of transmission lines and filters in distribution plants and vehicles (Dunn, 2009; Lee, Pfalzgraf, Poppe, Powers, \& Haines, 2007), mainly in seasonal countries and cold climate regions in tropical and subtropical countries. In Colombia, most problems have been reported in mixing and storage stations in cold climates (ICONTEC, 2013).

Biodiesel produced from Palm Oilis highly susceptible to form precipitates, formed mainly by sterol glucosides or mixes of Sterol Glucosides and Monoglycerides, which have a negative effect on cold flow properties and are responsible for filter and pipeline plugging (Kochhar, 1983; Moreau, Scott, \& Haas, 2008; Ringwald, 2007; Udomsap et al.; Van Hoed et al., 2008; Verleyen et al., 2002; Wang, Tang, Salley, $\& \mathrm{Ng}, 2010$ ). The presence of this kind of molecules is quantified through a quality parameter known as Total Contamination (Ministerio de Minas y Energía, 2007; Plata, Gauthier-Maradei, Romero-Bohorquez, Kafarov, \& Castillo, 2015). EN 12662, contained in EN 14214, is a method for determining contamination as the content of undissolved substances in middle distillates (in $\mathrm{mg} / \mathrm{kg}$ ), i.e., undissolved substances larger than $0.8 \mu \mathrm{m}$ (Knothe, 2006). Total Contamination is nowadays treated by sedimentation, but not always in a satisfactory way due to this procedure, it requires residence times up to 36 hours, therefore it is necessary the development of technological alternatives to obtain biodiesel within minimum quality requirements (He \& Van Gerpen, 2012). The use of adsorbent agents to remove the substances producing high values of Total Contamination is an alternative to solve the problems of pipe plugging and high amounts of sediments in storage tanks. However, the employed adsorbent must have no negative influence in other quality parameters of biodiesel. There are few studies reported in the literature on this topic despite of its utmost importance for the biodiesel industry and most of them don't include biodiesel obtained from Palm Oil (Bondioli, Cortesi, \& Mariani, 2008; He \& Van Gerpen, 2012; Tang, Salley, $\& \mathrm{Ng}, 2008)$.

Several techniques have been employed to reduce the amount of sterol glycosides from biodiesel and refined oils from which it is produced. It has been reported that neutralization and deodorization process reduce sterols content in vegetable oils (Verleyen, et al., 2002). It has been found a reduction from $70 \%$ to $10 \%$ of Phytosterols after vegetable oil refinement, and that through the transesterification reaction the acyl sterol glycosides are hydrolyzed to free sterol glycosides (Kochhar, 1983).

In other work, it was found that the concentration of sterol glycosides in biodiesel after treatment with bleaching earths is reduced from $68 \mathrm{ppm}$ to $20 \mathrm{ppm}$ (Lee, et al., 2007). Several techniques for removal of sterol glycosides from biodiesel, such as, vacuum distillation, cooling, centrifugation, and adsorption have been tested (Tang, De Guzman, Salley, \& Ng, 2010). Results show that every unit operation tested reduced the concentration of sterol glycosides but only vacuum distillation was able to remove soluble sterol glycosides. Biotechnology approaches have also been studied with good results at pilot plant scale, however, the addition of water to biodiesel to reduce the content of Steryl Glucosides implies additional unit operations and the recovery of enzymes is not straightforward (Aguirre et al., 2014; Peiru et al., 2015).

Ecopetrol S.A currently has a patent filed by the Colombian Superintendency of Industry and Commerce- SIC by resolution 98612, called "Process for the stabilization of Biodiesel" using bleaching earths.

In this work, we explored the use of three different commercially available bleaching earths, as adsorption agents for the reduction of Total Contamination in commercial samples of biodiesel. The effect of temperature and amount of bleaching earths on Total Contamination, moisture, pour point, and free and total glycerin was measured.

\section{EXPERIMENTAL DEVELOPMENT}

\section{Materials}

Sample recollection was performed according to procedure ISO 5555:2001 Animal and vegetable fats 
and oil-sampling. Samples were taken from a biodiesel storage tank of a biodiesel production facility which uses oil produced in the Colombian Caribbean Region. The biodiesel stored in the tank corresponded to a single production batch obtained during a week (2000 ton) and its properties are shown in Table 1, Bleaching Earths coded BE1, BE2, and BE3 are adsorbents with a proper surface area, and pore size for the retention of big molecules, such as non-hydrophilic phosphatides, soaps and metallic complex, among others. The main characteristics of the employed Bleaching Earth are shown in Table 2:

Table 1. Properties of the biodiesel employed in this study.

\begin{tabular}{|lll|}
\hline \multicolumn{1}{|c}{ Property } & \multicolumn{1}{c|}{ Value } & Method \\
\cline { 1 - 2 } Total Contamination & $121.7 \mathrm{mg} / \mathrm{kg}$ & EN 12662:2008 \\
\hline Free glycerin & $0.011 \% \mathrm{w} / \mathrm{w}$ & \\
\cline { 1 - 2 } Total glycerin & $0.122 \% \mathrm{w} / \mathrm{w}$ & \\
\cline { 1 - 2 } Monoglycerides & $0.322 \% \mathrm{w} / \mathrm{w}$ & \multirow{2}{*}{ ASTM D6584-10a } \\
\cline { 1 - 2 } Diglycerides & $0.117 \% \mathrm{w} / \mathrm{w}$ & \\
\hline Triglycerides & $0.000 \% \mathrm{w} / \mathrm{w}$ & \\
\hline Moisture & $393 \mathrm{mg} / \mathrm{kg}$ & ASTM E203-08 \\
\hline
\end{tabular}

Table 2. Properties of bleaching earths employed in this study.

\begin{tabular}{|l|ccc|}
\hline Bleaching Earth & BE1 & BE2 & BE3 \\
\hline Moisture (\%) & $10,0 \% \pm 5,0 \%$ & $10,0 \% \pm 5,0 \%$ & $10,0 \% \pm 5,0 \%$ \\
\hline $\mathrm{pH}$ & 8,1 & 2,5 & 8,1 \\
\hline Bulk density (g/L) & 400 & 400 & 450 \\
\hline Free acidity & - & $5,0 \% \pm 1,0 \%$ & - \\
\hline
\end{tabular}

\section{Sample preparation}

The storage tank sample was divided into three equal amounts: one of them was cooled and kept at $0{ }^{\circ} \mathrm{C} \pm 0.5$ ${ }^{\circ} \mathrm{C}$ during a day; the second portion was cooled and kept at $15^{\circ} \mathrm{C} \pm 0.5^{\circ} \mathrm{C}$ during a day; and the third one was kept at $30 \pm 0.8^{\circ} \mathrm{C}$ (room temperature). After cooling, the first two portions of the sample were allowed to warm at room temperature for a day, prior to experiments.

\section{Adsorption experiments}

For each Bleaching Earth and cooling temperature, mixtures of $0.0,0.25,0.50,0.75,1.00$, and $1.25 \% \mathrm{w} / \mathrm{w}$ of bleaching earths with biodiesel were made. The mixture of $0.0 \%$ was taken as a control in a factorial experimental design with three levels for temperature and six levels for the dose of Bleaching Earth for each kind of bleaching earth.

The required amount of Bleaching Earth was added to 11 of biodiesel and it was stirred at 30 RPM for 30 $\mathrm{min}$. The mixture was allowed to settle for $30 \mathrm{~min}$ and then the supernatant was vacuum filtered ( $20-60$ mbar) through filter paper of $5 \mu \mathrm{m}$.

\section{Characterization}

The filtered biodiesel was characterized measuring moisture content using Karl-Fisher (ASTM E20308); free and total glycerin using gas chromatography (Agilent 7890A) with flame ionization detection (FID) as described in ASTM D6584-10a; Total Contamination as described in EN 12662:2008; and pour point using the procedure described in ASTM D-97.

\section{Experimental Design}

A full factorial experimental design $3 \times 6 \times 3$ was employed and each experiment was done in triplicate. The manipulated variables were: type of Bleaching Earth (three levels: BE1, BE2, and BE3), concentration of Bleaching Earth (six levels: $0 \%, 0.25 \%, 0.50 \%, 0.75 \%$, $1.00 \%$, and $1.25 \% \mathrm{w} / \mathrm{w}$ ), and temperature (three levels: $0{ }^{\circ} \mathrm{C}, 15^{\circ} \mathrm{C}$ and $30{ }^{\circ} \mathrm{C}$ ). The main objective of this work was to determinate the effect of these manipulated variables on the response variable Total Contamination, although other quality parameters, such as, moisture and free and total glycerin were also measured and taken as response variables.

\section{RESULTS AND DISCUSSION.}

\section{Effect of manipulated variables}

The analysis of variance of the data for the three types of bleaching earths employed in this study, for the response variables Total Contamination and moisture, are shown in Tables 3 and 4 respectively. For bleaching earths BE3 and BE1, the analysis of variance shows a significant effect $(p<0.01)$ of the manipulated variables dose of Bleaching Earth and temperature, and also on their interaction of the response variables, Total Contamination and moisture. For the Bleaching Earth BE2, only the dose of Bleaching Earth showed a significant effect on Total Contamination $(p<0.05)$ 
and on moisture of the biodiesel $(\mathrm{p}<0.01)$, whereas temperature showed to be not significant.

In Figure 1, the effect of manipulated variables on Total Contamination is shown. A strong correlation between temperature and Total Contamination is observed: at higher temperatures higher adsorption of contaminants is found for the three types of earths with a much less pronounced effect in the case of BE2. These results suggest that pre-cooling of samples does not improve the adsorption of the components causing the Total Contamination, if this is not removed immediately after precipitation at low temperatures. Possibly, aggregation of biodiesel contaminants originating from the low temperature storage, avoids diffusion of these components to the adsorption sites of the bleaching earth, decreasing performance for the adsorption process of the insoluble material.

Table 3. Analysis of variance for Total Contamination in biodiesel samples from palm oil.

\begin{tabular}{|l|ccc|}
\hline \multicolumn{1}{|c}{$\begin{array}{c}\text { Type of } \\
\text { bleaching Earth }\end{array}$} & BE1 & BE2 & BE3 \\
\hline A:Dose of adsorbent & 0.0001 & 0.0000 & 0.0186 \\
\hline B:Temperature & 0.0000 & 0.0000 & 0.0570 \\
\hline AA & 0.0035 & 0.0000 & 0.4727 \\
\hline$A B$ & 0.0000 & 0.0000 & 0.2091 \\
\hline BB & 0.7564 & 0.0276 & 0.7657 \\
\hline
\end{tabular}

Table 4. Analysis of variance for moisture in biodiesel samples from palm oil

\begin{tabular}{|l|c|c|c|}
\hline \multicolumn{1}{|c|}{$\begin{array}{c}\text { Type of } \\
\text { bleaching Earth }\end{array}$} & BE3 & BE1 & BE2 \\
\hline A:Dose of adsorbent & 0.0000 & 0.0000 & 0.0000 \\
\hline B:Temperature & 0.0000 & 0.0011 & 0.2977 \\
\hline $\mathrm{AA}$ & 0.0000 & 0.0000 & 0.0000 \\
\hline $\mathrm{AB}$ & 0.0000 & 0.0000 & 0.0006 \\
\hline $\mathrm{BB}$ & 0.1169 & 0.0015 & 0.5298 \\
\hline
\end{tabular}

Moreover, the behavior of the Total Contamination with the dose of earth is much more complex, with minima in some cases and maxima in others depending on the kind of Bleaching Earth and temperature. Some of these experimental results were discarded in the

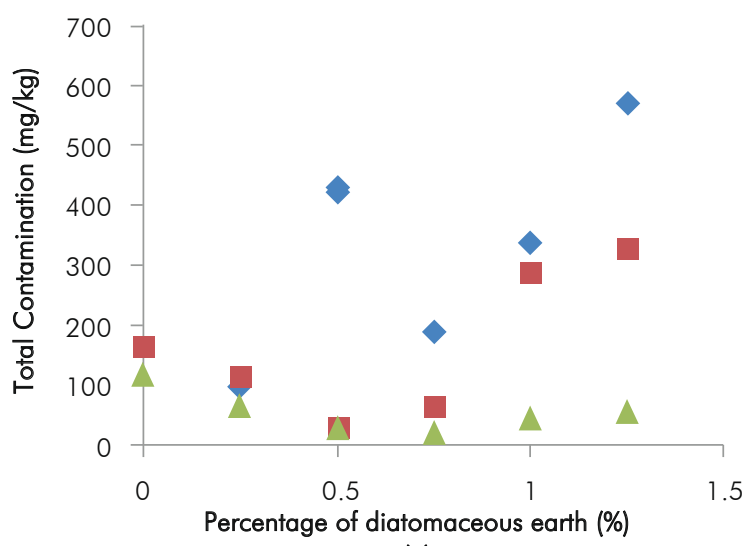

(a)

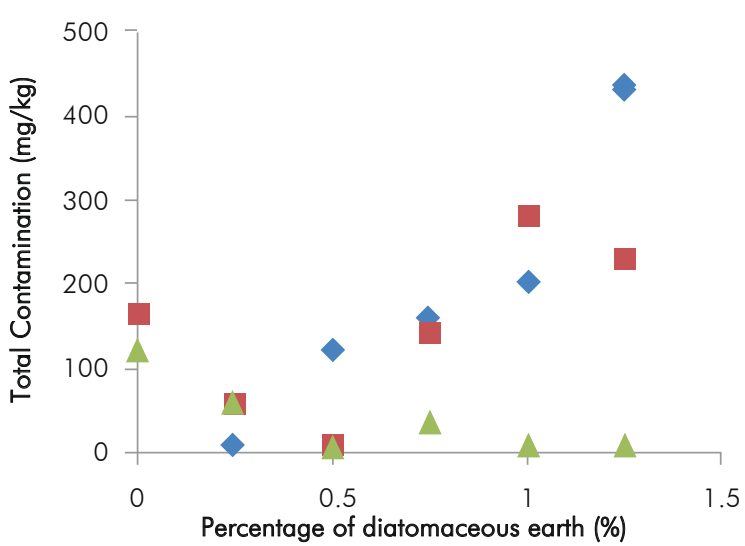

(b)

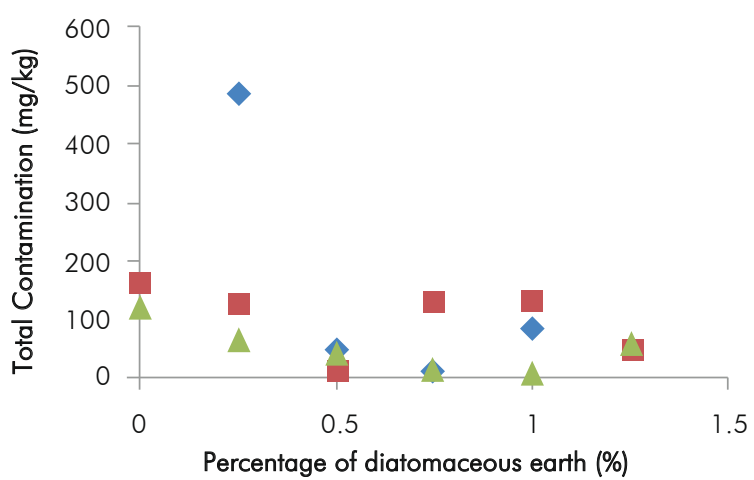

(c)

Figure 1. Effect of the dose of Bleaching Earth on Total Contamination in biodiesel samples treated at several temperatures: a) BE3; b) BE 1 and c) BE2

optimization analysis conducted because they negatively affected the goodness of fit of the models employed. For most bleaching earths and temperatures, the Total Contamination initially decreases with low doses of bleaching earth, and at higher amounts of earths it 
starts to increase, possibly due to the bleaching of an unidentified substance from the adsorbent to the biodiesel at high doses of the adsorbent.

Figure 2, shows the behavior of the moisture with the dose of earth and temperature. The behavior of this variable is less complex and curves have a smoother trend than in the case of the Total Contamination. For low temperatures, biodiesel moisture initially increases as the dose of earth increases, but at higher values of the dose of earth, biodiesel moisture tends to stabilize or decrease slightly. Whatever the case, treatment with the studied earths increases the moisture content in biodiesel, in most cases above the limit permitted under Colombian law and by international standards (Kochhar, 1983; Resolución 182142 de 2007 Ministerio de Minas y Energía, 2007). This behavior suggests that bleaching earths either release moisture toward the biodiesel or catalyze reactions with water as one of the products.

The effect of temperature depends on the type of earth and shows considerable complexity: in the case of BE1 and BE3, at low earth concentrations, moisture increases at low temperatures, and the opposite behavior is observed at high Bleaching Earth concentrations, with the effect more marked for BE3 than for BE1. For earth $\mathrm{BE} 2$, as mentioned above, the effect of temperature and concentration is little marked; however, treatments with this Bleaching Earth are the ones with the lowest levels of Total Contamination. These results are in accordance with the obtained using bleaching earths and magnesium silicate at higher temperatures than those used in our study, where maxima of adsorptions capacity of Steryl Glucosides were found at low adsorbent doses and almost no dependence with temperature was found at high adsorbent doses, i. e., a complex behavior was found with temperature and adsorbent dose (Na-Ranong, Laungthaleongpong, \& Khambung, 2015). Similar removals of Steryl Glucosides were obtained using other adsorbents similar to the ones used in our study, and also a negative influence of temperature on adsorption of Steryl Glucoside was found (Plata, Haagenson, Dağdelen, Wiesenborn, \& Kafarov, 2015).

\section{Optimization}

Experimental data of Total Contamination were fitted to a polynomial of the form shown in Equation 1.

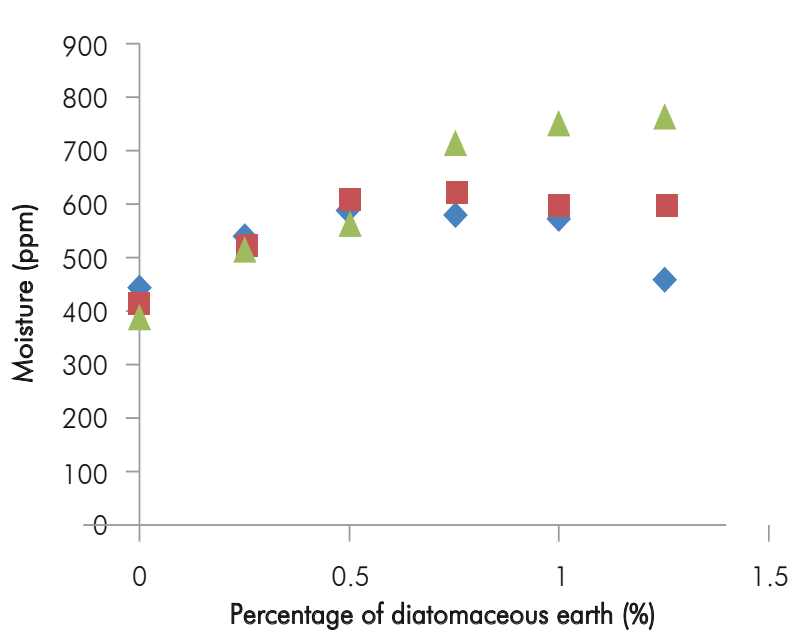

(a)

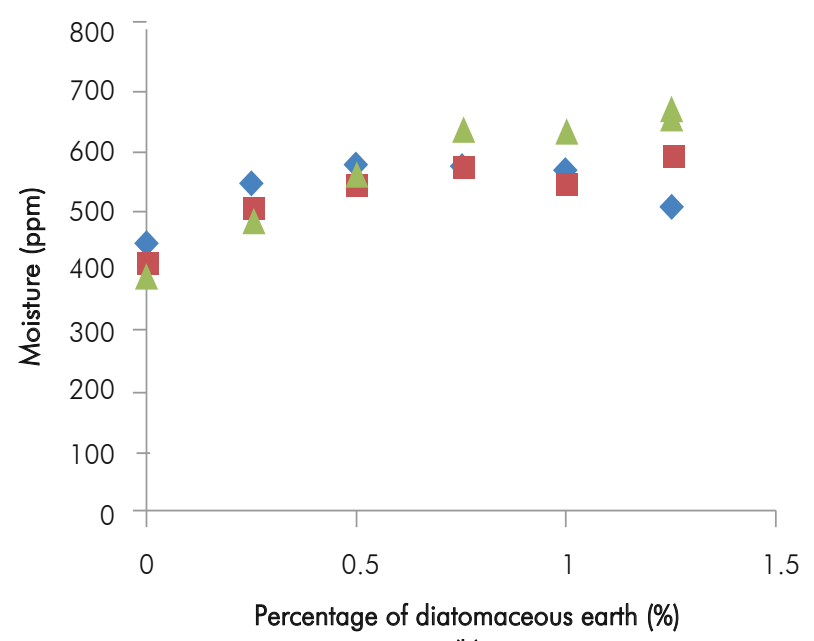

(b)

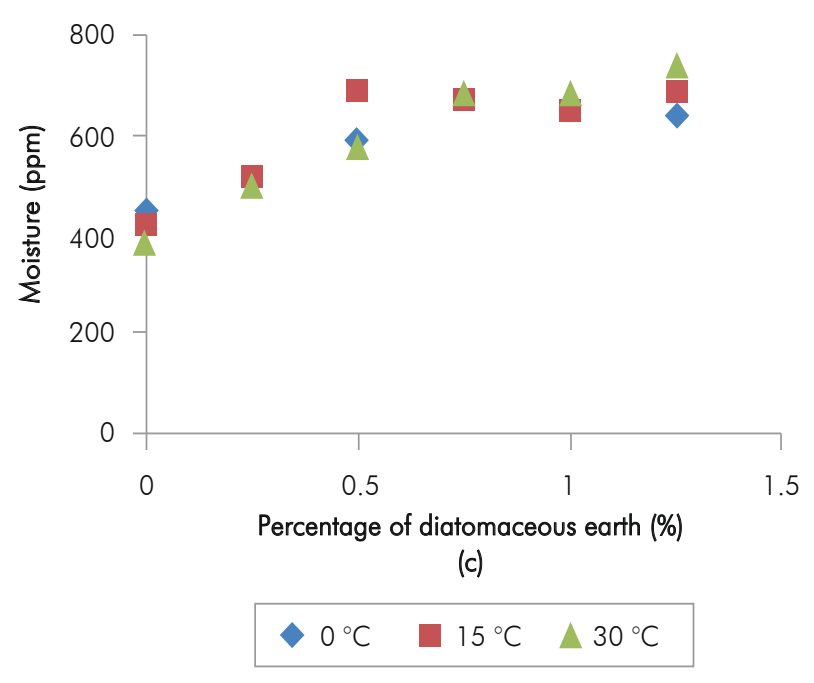

Figure 2. Effect of the dose of Bleaching Earth on the moisture of biodiesel samples treated at several temperatures: a) BE3; b) BE 1 and c) BE2. 


$$
\begin{array}{r}
C T(x, y)=p_{00}+p_{10} \cdot x+p_{01} \cdot y+p_{20} \cdot x^{2}+p_{11} \cdot x \cdot y+p_{00} \cdot y^{2}+p_{30} \cdot x^{3} \\
+p_{21} \cdot x^{2} \cdot y+p_{12} \cdot x^{2} \cdot y^{2}
\end{array}
$$

Where, CT is the Total Contamination and $\mathrm{x}$ and $\mathrm{y}$ represent the percentage of Bleaching Earth and temperature, respectively. The $p$, parameters are the coefficients of the polynomial fit. Fit of the experimental data was performed using the adjustment tools of MatLab $\AA$. The contour plots, results of adjustments made, are shown in Figure 3 and the fitting parameters in Table 5 , where it can be seen that there is a very good fit of the model for the earths BE1 and BE3 and a very poor fit for the earth BE2, which agrees with the results of the analysis of variance performed, which showed very low levels of confidence to the dependence of the response variables with temperature and dose of earth, for the latter adsorbent.

From Figure 3, it can be seen that only in a very limited range of doses of Bleaching Earth and at high temperatures bleaching earths BE3 and BE1 managed to reduce the Total Contamination below the standard requirements $(24 \mathrm{mg} / \mathrm{kg})$. In the case of the treatment with the Bleaching Earth BE2, Figure 3, shows that it fails to meet the requirements of the standard under the conditions studied. However this statement is wrong, and it is the result of the poor fitting of the model, as it can be seen in Figure 1 where it is showed that this earth is the one that achieves the lowest levels of Total Contamination.

The boundary curves for the variable moisture are shown in Figure 4 and the corresponding fitting parameters in Table 5. From Figure 3 and 4, it can be seen that there are not common areas where the Total Contamination and moisture are below than those required by the standard normative, because, in the optimization of variables, priority was given to the Total Contamination and moisture was taken as a secondary constraint.

For this optimization, the conditions that maximize the desirability function defined as shown in equation 2 were searched:

$d=\left\{\begin{array}{cl}\left(\frac{\hat{y}-\text { high }}{\text { low-high }}\right) & ,, \hat{y}<\text { low } \leq \hat{y} \leq \text { high } \\ 0 & , \hat{y}>\text { high }\end{array}\right.$

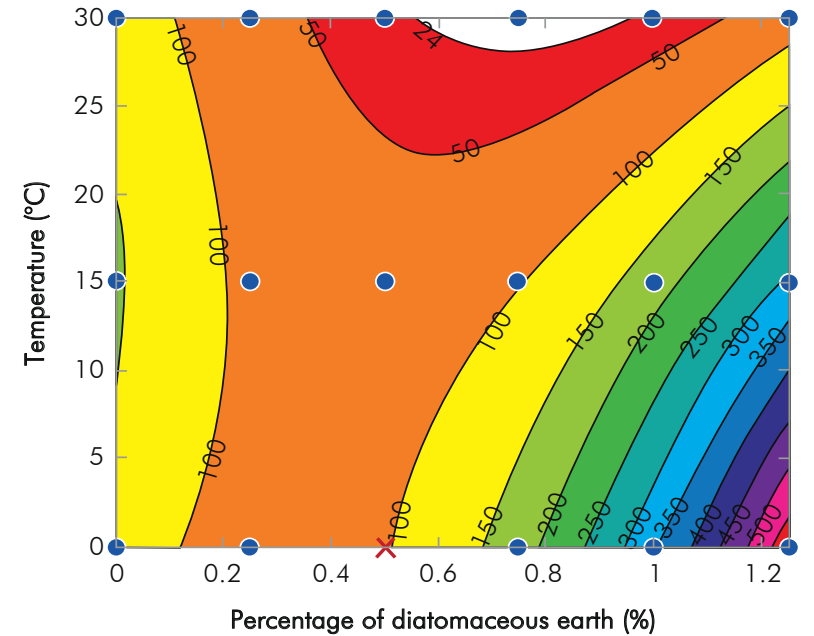

(a)

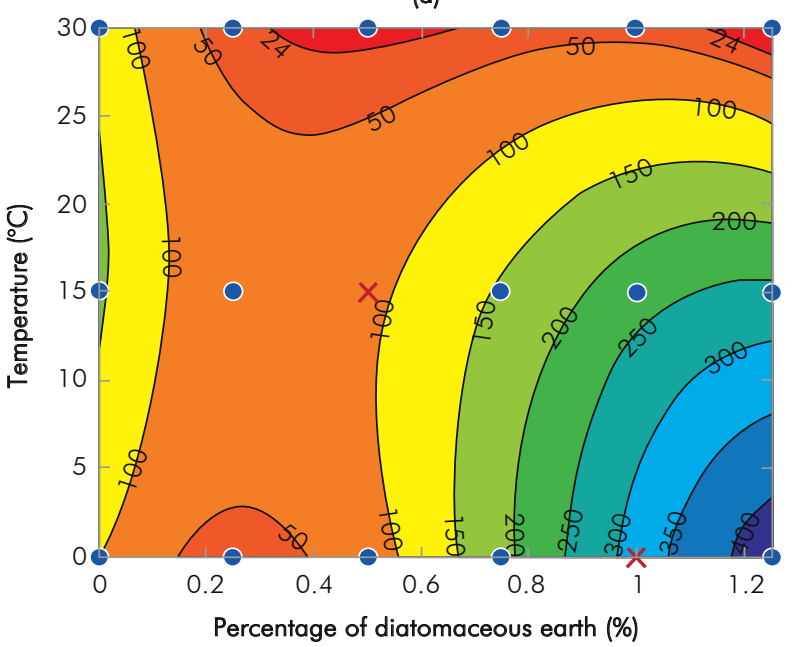

(b)

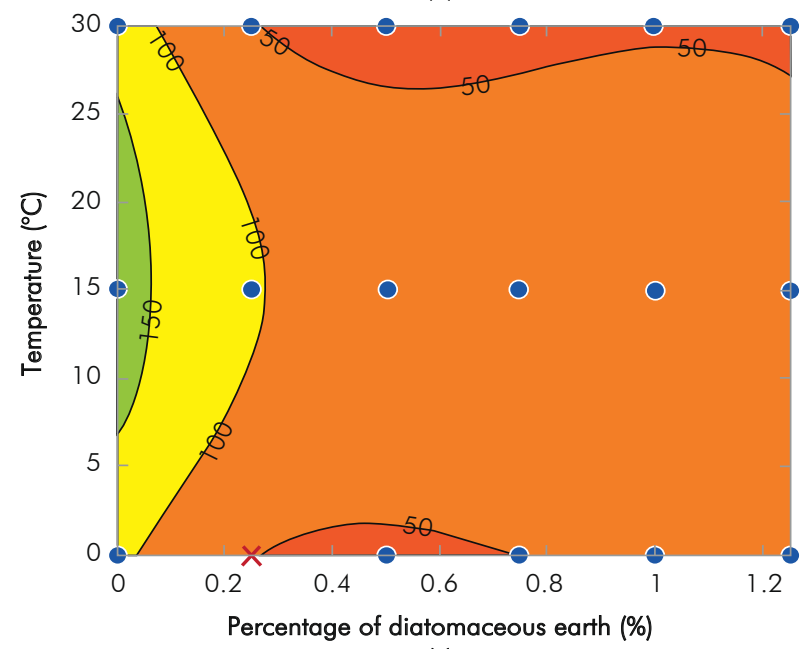

(c)

- Experimental Point $X$ Excluded point

Figure 3. Contour plot for Total Contamination $(\mathrm{mg} / \mathrm{kg})$ in treated biodiesel samples: a) BE3; b) BE1 and c) BE2. 


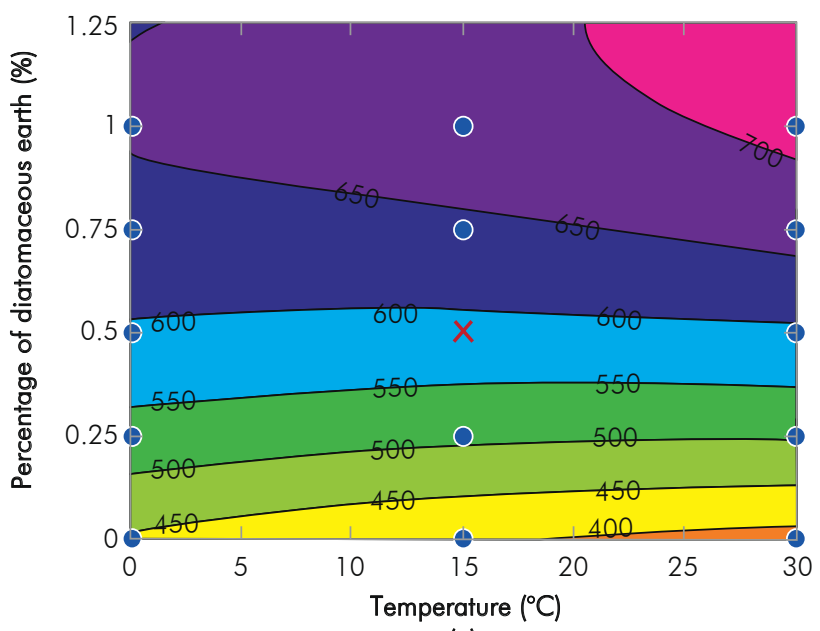

(a)

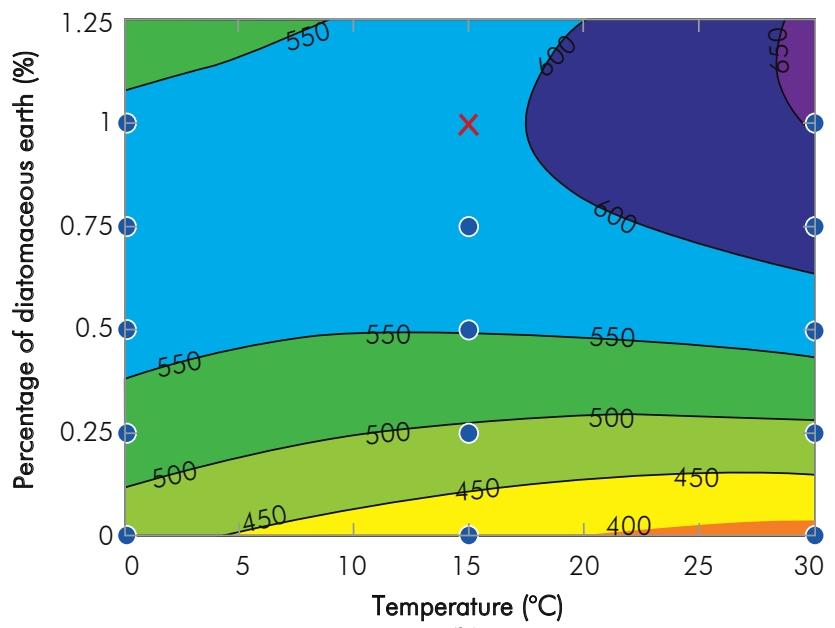

(b)

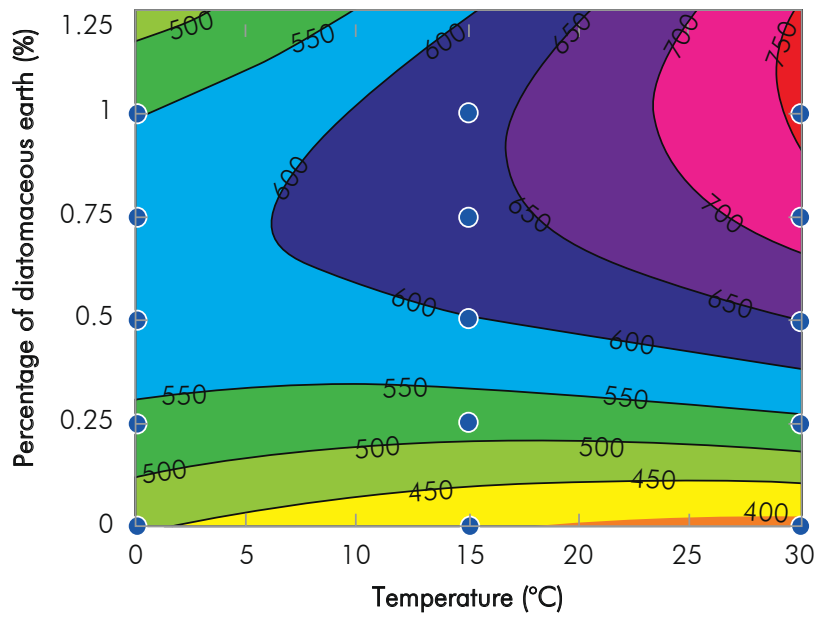

(c)

Experimental Point $\times$ Excluded point

Figure 4. Contour plot for moisture $(\mathrm{mg} / \mathrm{kg})$ in treated biodiesel samples with: a) BE3; b) BEl and c) BE2.
Where $d$ is the desirability and varies from 0 to 1 ; and $\hat{y}$ is the predicted value of the response variable, "high" is a value above which the response is totally unacceptable $(24 \mathrm{mg} / \mathrm{kg}$ for Total Contamination, and 500 ppm for moisture) and "low" a value below which desirability is a maximum. This equation applies to both total contamination and moisture. Subsequently desirabilities of the response variable are combined through the mathematical expression of equation 3 :

$$
D=\left\{\mathrm{d}_{1}^{I_{1}}, \mathrm{~d}_{2}^{I_{2}} \ldots \mathrm{d}_{m}^{I_{m}}\right\}^{1 / \sum_{j=1 I_{j}}^{m}}
$$

Where, $D$ is the composite desirability function and $I$ is the attributed impact for each response variable. This last ranges from 1 to 5 and the higher the value, the corresponding response variable is more important.

Table 5. Adjusted parameters of the response variables to polynomial models

\begin{tabular}{|c|c|c|c|}
\hline Coefficient & BE3 & BE1 & BE2 \\
\hline \multicolumn{4}{|c|}{ Total Contamination } \\
\hline p00 & 132.3 & 106.2 & 109.8 \\
\hline plo & -322.5 & -560.3 & -357.5 \\
\hline p01 & 3.092 & 5.948 & 7.846 \\
\hline p20 & 475.5 & 1254 & 557.7 \\
\hline pl1 & -2.56 & -0.5849 & -3.92 \\
\hline p02 & -0.1077 & -0.1668 & -0.2402 \\
\hline p30 & 56.18 & -479.9 & -248.2 \\
\hline p21 & -12.2 & -8.285 & 1.445 \\
\hline p12 & 0.1485 & -0.0513 & 0.03912 \\
\hline R2 & 0.9634 & 0.946 & 0.5995 \\
\hline \multicolumn{4}{|c|}{ Moisture } \\
\hline p00 & 458.4 & 469.1 & 441.3 \\
\hline p10 & -4.698 & -4.715 & -2.881 \\
\hline p01 & 396.1 & 286.6 & 396.9 \\
\hline p20 & 0.07804 & 0.06356 & 0.0356 \\
\hline pl1 & 9.365 & 5.87 & 3.772 \\
\hline p02 & -307.1 & -195.3 & -185.5 \\
\hline R2 & 0.9655 & 0.962 & 0.9704 \\
\hline
\end{tabular}


The values of the weights and impacts used for these two variables in the desirability function employed for the optimization are shown in Table 6 . The values that maximize the desirability function are found in the same table. It is observed that among the optimum found, treated biodiesel presents values of Total Contamination below the levels stipulated by the regulations, however, it also has a moisture higher than the maximum allowed $(500 \mathrm{mg} / \mathrm{kg})$.

Table 6. Parameters of the desirability function and values of the optimum.

\begin{tabular}{|ccc|} 
& BE3 & BE1 \\
& Total Contamination & \\
\hline Weigth & 8.5 & 2.8 \\
\hline Impact & 5 & 5 \\
\hline Value $(\mathrm{mg} / \mathrm{kg})$ & 21.01 & 5.5 \\
\hline & Moisture & \\
\hline Weigth & 0.1 & 0.1 \\
\hline Impact & 1.0 & 1.0 \\
\hline Value $(\mathrm{mg} / \mathrm{kg})$ & 621 & 562 \\
\hline Desirability & 0.98488 & 0.984408 \\
\hline Dose of Bleaching & & 0.48 \\
\hline Earth $(\%)$ & 0.48 & 30 \\
\hline Temperature $\left({ }^{\circ} \mathrm{C}\right)$ & 30 & \\
\hline
\end{tabular}

When compared with other studies (Dunn, 2009; He \& Van Gerpen, 2012), the results obtained in this work show a fairly high level of removal, even superior to that obtained with a combination of techniques such as cold filtration, and adsorption with earths of different specification. Ultrafiltration has been reported as a promising technique for the removal of Steryl Glucosides, achieving final Steryl Glucoside concentrations below the reported in this work, but it requires change in reaction conditions and it is an energy intensive technique (Tremblay \& Montpetit, 2017). Removal of Steryl Glucosides with bleaching earths and magnesium silicate show similar results than reported in our work, despite, Total Contamination and Steryl Glucoside content are no interchangeable concepts, and the Steryl Glucosides are part of the substances quantified in Total Contamination (Na-Ranong, D., Laungthaleongpong, P., \& Khambung, S., 2015).

\section{Pour Point; Free and Total Glycerin}

In the case of free and total glycerin, it was found that, for most treatments, these parameters were reduced when compared to non-treated biodiesel, which had an initial content of $0.011 \%$ and $0.122 \%$ by weight of free and total glycerin, respectively (Figure 5). From these results, it can be seen that earth treatments help to reduce or maintain unchanged the content of free and total glycerin in the biodiesel. In just one treatment (BE2; dose of Bleaching Earth $1 \%$; temperature $15^{\circ} \mathrm{C}$ ), an increased value for these properties was observed.

On the other hand, the value of the pour point was measured for 20 samples which treatment yielded some reduction in the Total Contamination of biodiesel. The obtained results showed that the pour point is not affected by the treatment with the studied earths, yielding a constant value of $15^{\circ} \mathrm{C}$.

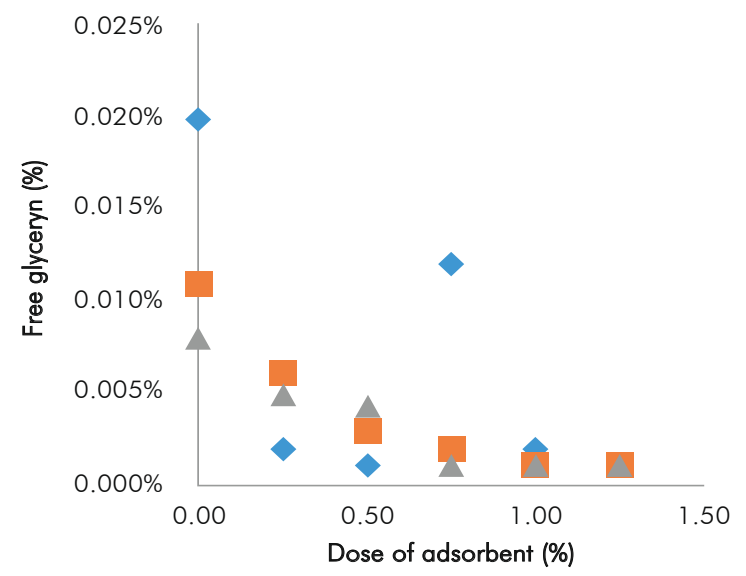

(a)

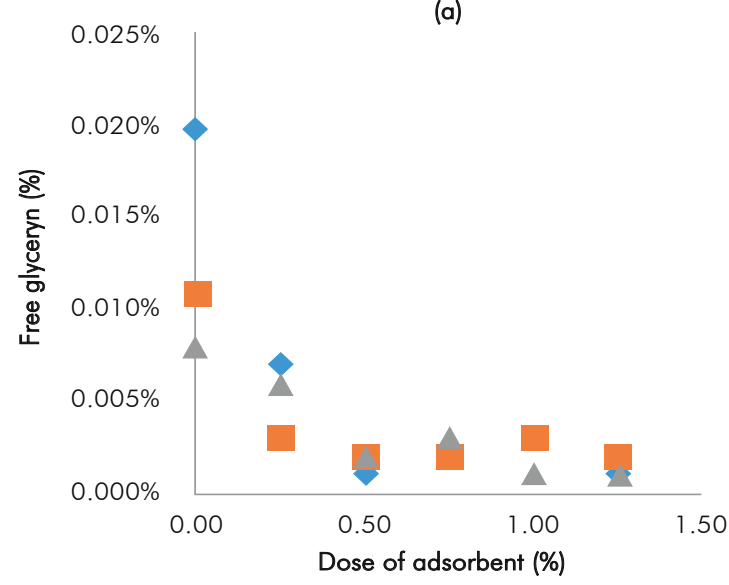

(b)

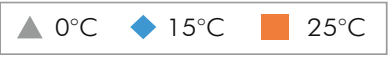

Figure 5. Content of free and total glycerin for samples treated bleaching earths. Free glycerin: a) BE3; b) BE1 and c) BE2. Total glycerin: d) BE3; d) BE 1 and f) BE2. 

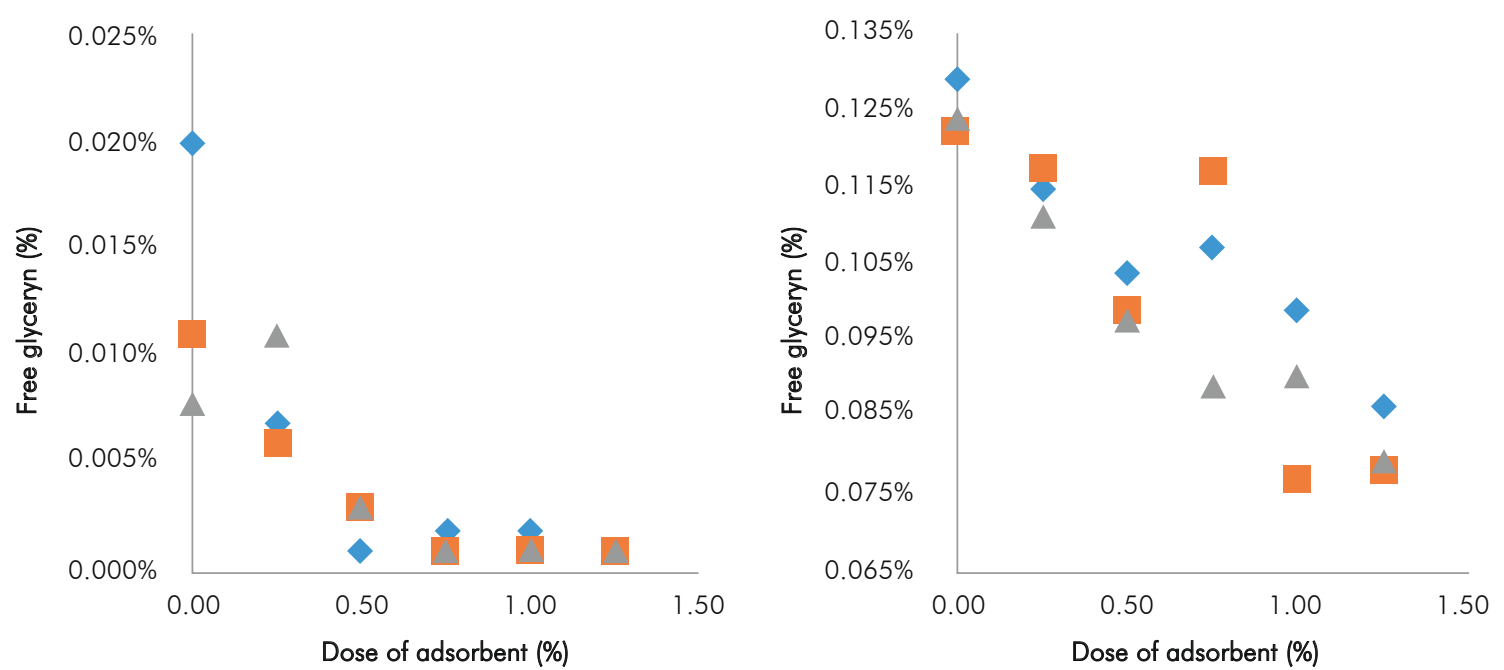

(c)
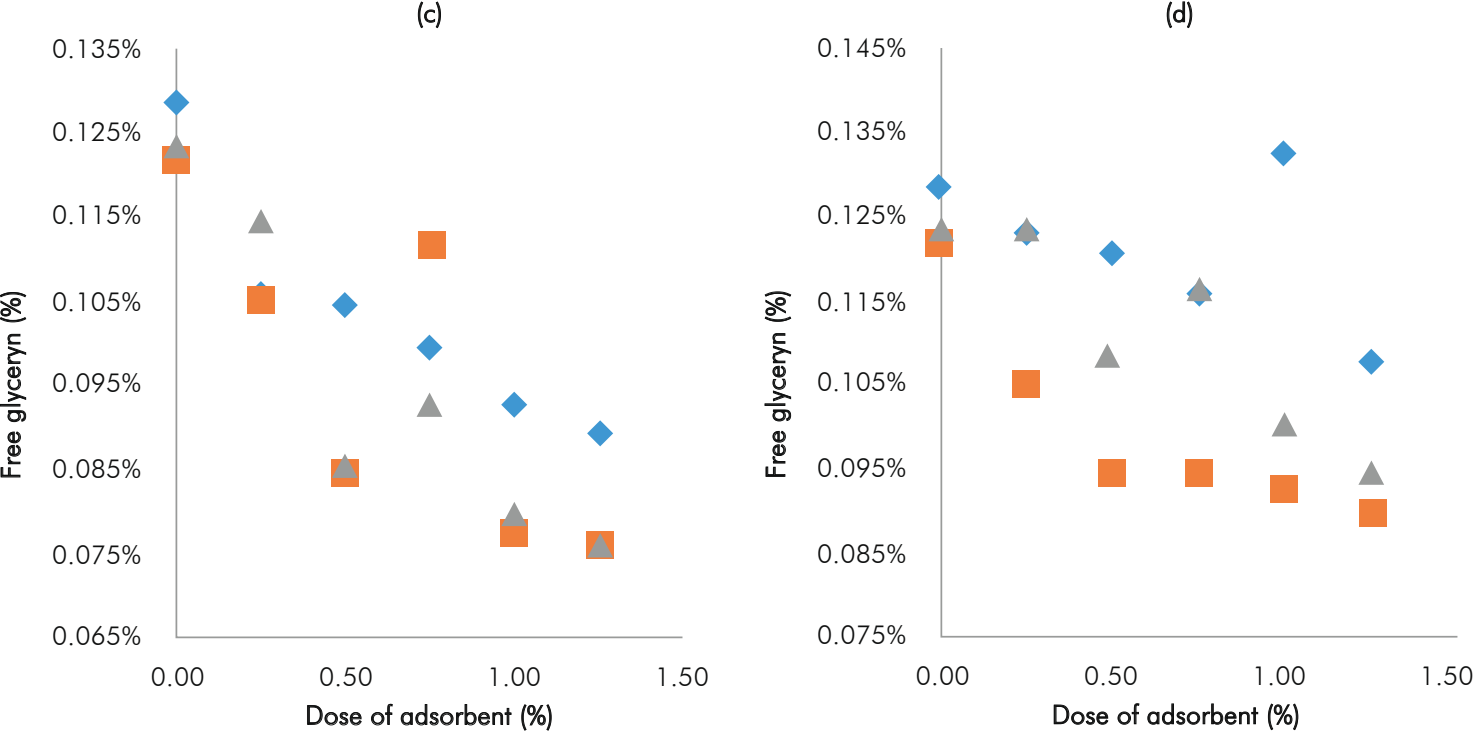

(e)

(f)

\section{$\triangle 0^{\circ} \mathrm{C}>15^{\circ} \mathrm{C}-25^{\circ} \mathrm{C}$}

Figure 5. Content of free and total glycerin for samples treated bleaching earths. Free glycerin: a) BE3; b) BE1 and c) BE2. Total glycerin: d) BE3; d) BE1 and f) BE2. (Continuation)

\section{CONCLUSIONS}

- The use of the studied bleaching earths shows good potential for reducing the Total Contamination in the Colombian biodiesel, achieving levels below those stipulated in Resolution 182142 of 2007. However, this treatment increases moisture in biodiesel above the maximum allowed, which would imply that further treatment should be performed on biodiesel to remove excess moisture.

- By optimization of the model employed, it was determined that the optimum operating point for BE3 and $\mathrm{BE} 1$ earths occurs at $24^{\circ} \mathrm{C}$ and a mixing ratio of earth: biodiesel of $0.5 \%$ by weight. Other properties of biodiesel, such as Free and Total Glycerin, were improved in most treatments. The pour point was not changed with the treatments with bleaching earths.

\section{REFERENCES}

Aguirre, A., Peiru, S., Eberhardt, F., Vetcher, L., Cabrera, R., \& Menzella, H. G. (2014). Enzymatic hydrolysis of Steryl Glucosides, major contaminants of vegetable oil-derived Biodiesel. Applied Microbiology and Biotechnology, 98(9), 4033-4040. DOI: 10.1007/s00253-013-5345-4 
Bondioli, P., Cortesi, N., \& Mariani, C. (2008). Identification and quantification of Steryl Glucosides in Biodiesel. European Journal of Lipid Science and Technology, 110(2), 120-126. DOI: 10.1002/ejlt.200700158

Dunn, R. O. (2009). Effects of minor constituents on cold flow properties and performance of Biodiesel. Progress in Energy and Combustion Science, 35(6), 481-489. DOI: 10.1016/j.pecs.2009.07.002

He, B. B., \& Van Gerpen, J. H. (2012). Analyzing Biodiesel for contaminants and moisture retention. Biofuels, 3(3), 351-360. DOI: 10.4155/bfs.12.19

ICONTEC. Buenas prácticas de manejo para el biodiésel y las mezclas diésel-biodiésel en la cadena de distribución de combustibles líquidos derivados de petróleo en Colombia, NTC-6032 C.F.R. (2013).

Knothe, G. (2006). Analyzing Biodiesel: standards and other methods. Journal of the American Oil Chemists' Society, 83(10), 823-833.

Kochhar, S. (1983). Influence of processing on sterols of edible vegetable oils. Progress in Lipid Research, 22(3), 161-188. DOI:10.1016/0163-7827(83)90008-5.

Lee, I., Pfalzgraf, L. M., Poppe, G. B., Powers, E., \& Haines, T. (2007). The role of sterol glucosides on filter plugging. Biodiesel. Mag., 4, 105-112.

Resolución 182142 de 2007. Ministerio de Minas y Energía de Colombia. (2007).

Moreau, R. A., Scott, K. M., \& Haas, M. J. (2008). The identification and quantification of Steryl Glucosides in precipitates from commercial Biodiesel. Journal of the American Oil Chemists' Society, 85(8), 761-770.

Na-Ranong, D., Laungthaleongpong, P., \& Khambung, S. (2015). Removal of Steryl Glucosides in Palm Oilbased Biodiesel using magnesium silicate and bleaching earth. Fuel, 143, 229-235. DOI: 10.1016/j.fuel.2014.11.04

Peiru, S., Aguirre, A., Eberhardt, F., Braia, M., Cabrera, R., \& Menzella, H. G. (2015). An industrial scale process for the enzymatic removal of Steryl Glucosides from Biodiesel. Biotechnology for Biofuels, 8(1), 223. DOI 10.1186/ s13068-015-0405-x
Plata, V., Gauthier-Maradei, P., Romero-Bohórquez, A. R., Kafarov, V., \& Castillo, E. (2015). Characterization of insoluble material isolated from Colombian Palm Oil Biodiesel. Biomass and Bioenergy, 74, 6-14.

Plata, V., Haagenson, D., Dağdelen, A., Wiesenborn, D., \& Kafarov, V. (2015). Improvement of Palm OilBiodiesel filterability by adsorption methods. Journal of the American Oil Chemists' Society, 92(6), 893-903. DOI: 10.1007/ s11746-015-2646-z

Ringwald, S. (2007). Biodiesel characterisation in the QC environment. Paper presented at the Proceedings of the 98th AOCS meeting, Québec City.

Tang, H., De Guzman, R., Salley, S., \& Ng, K. S. (2010). Comparing process efficiency in reducing Steryl Glucosides in Biodiesel. Journal of the American Oil Chemists' Society, 87(3), 337-345. DOI 10.1007/s11746-009-1502-4

Tang, H., Salley, S. O., \& Ng, K. S. (2008). Fuel properties and precipitate formation at low temperature in soy-, cottonseed-, and poultry fat-based Biodiesel blends. Fuel, 87(13), 3006-3017. DOI: 10.1016/j.fuel.2008.04.030

Tremblay, A. Y., \& Montpetit, A. (2017). The in-process removal of sterol glycosides by ultrafiltration in Biodiesel production. Biofuel Research Journal, 4(1), 559-564. DOI: 10.18331/BRJ2017.4.1.6

Udomsap, P., Sahapatsombut, U., Puttasawat, B., Krasae, P., Goodwin, V., Chollacoop, N., \& Topaiboul, S (2008). Characterization of Insoluble Impurities in Biodiesel from Palm Stearin. Encuentro de la Asociación de Ingenieros Mecánicos de Tailandia ME-NETT 22: 70-73

Van Hoed, V., Zyaykina, N., De Greyt, W., Maes, J., Verhé, R., \& Demeestere, K. (2008). Identification and occurrence of Steryl Glucosides in palm and soy Biodiesel. Journal of the American Oil Chemists' Society, 85(8), 701-709. DOI: $10.1007 / \mathrm{s} 11746-008-1263-5$

Verleyen, T., Sosinska, U., Ioannidou, S., Verhé, R., Dewettinck, K., Huyghebaert, A., \& De Greyt, W. (2002). Influence of the vegetable oil refining process on free and esterified sterols. Journal of the American Oil Chemists' Society, 79(10), 947-953. DOI: 10.1007/s11746-002-0585-4

Wang, H., Tang, H., Salley, S., \& Ng, K. S. (2010). Analysis of sterol glycosides in Biodiesel and Biodiesel precipitates. Journal of the American Oil Chemists' Society, 87(2), 215221. DOI 10.1007/s11746-009- 


\section{AUTHORS}

\section{Alberto Ricardo Albis Arrieta}

Affiliation: Facultad de Ingeniería, Universidad del Atlántico,

Barranquilla, Colombia.

e-mail: albertoalbis@uniatlantico.edu.co

\section{Carlos Alberto Barros Mendoza}

Affiliation: Facultad de Ingeniería, Universidad del Atlántico,

Barranquilla , Colombia.

e-mail: cbarrosmendoza@uniatlantico.edu.co

\section{Oscar Eliecer Cabarcas Núñez}

Affiliation: Facultad de Ingeniería, Universidad del Atlántico,

Barranquilla , Colombia.

e-mail: oscarcabarcasjr@yahoo.com 